\title{
Gadolinite-(Nd), a new member of the gadolinite supergroup from Fe-REE deposits of Bastnäs-type, Sweden
}

\author{
Radek ŠKoda ${ }^{1, *}$, Jakub Plášil $^{2}$, Renata Čopjaková ${ }^{1}$, Milan Novák ${ }^{1}$, Erik Jonsson ${ }^{3,4}$, Michaela \\ VAŠINOVÁ GaLIOVÁ ${ }^{1,5,6}$ AND Dan Holtstam ${ }^{7}$ \\ 1 Department of Geological Sciences, Faculty of Science, Masaryk University, Kotlářská 2, CZ-611 37 Brno, \\ Czech Republic \\ 2 Institute of Physics ASCR, v.v.i., Na Slovance 2, Praha 8, CZ-182 21, Czech Republic \\ 3 Department of Mineral Resources, Geological Survey of Sweden, Box 670, SE-751 28 Uppsala, Sweden \\ 4 Department of Earth Sciences, Uppsala University, SE-752 36 Uppsala, Sweden \\ 5 Department of Chemistry, Faculty of Science, Masaryk University, Kotlárská 2, CZ-611 37 Brno, Czech Republic \\ 6 Central European Institute of Technology (CEITEC), Masaryk University, Kamenice 5, CZ-625 00 Brno, \\ Czech Republic \\ 7 Swedish Research Council, Box 1035, SE-101 38 Stockholm, Sweden
}

[Received 26 January 2017; Accepted 7 June 2017; Associate Editor: John Bowles]

\section{ABSTRACT}

A new member of the gadolinite supergroup, gadolinite-(Nd), IMA2016-013, ideally $\mathrm{Nd}_{2} \mathrm{FeBe}_{2} \mathrm{Si}_{2} \mathrm{O}_{10}$, was found in the Malmkärra mine, $\sim 3.5 \mathrm{~km}$ WSW of Norberg, south-central Sweden, where it occurs in association with fluorbritholite-(Ce), västmanlandite-(Ce), dollaseite-(Ce), bastnäsite-(Ce) and tremolite. Gadolinite-(Nd) forms anhedral grains up to $150 \mu \mathrm{m}$ in size, commonly occurring as aggregates of olive green colour. The crystals are transparent with vitreous to adamantine lustre. Gadolinite-(Nd) is brittle with conchoidal fracture, no cleavage or parting was observed. It has a white streak, the Mohs hardness is 6.5-7 and the calculated density is $4.86 \mathrm{~g} \mathrm{~cm}^{-3}$. Optically, the mineral is weakly pleochroic in shades of olive green, biaxial $(-), \mathrm{n}_{\alpha}=1.78(1), \mathrm{n}_{\beta \text { (calc.) }}=1.80, \mathrm{n}_{\gamma}=1.81(1)$ measured in white light, $2 \mathrm{~V}_{\text {(meas.) }}=62(3)^{\circ}$. Electron-microprobe and laser ablation inductively coupled plasma mass spectrometry analysis [in wt.\%] provided $\mathrm{SiO}_{2} 21.77, \mathrm{Y}_{2} \mathrm{O}_{3} 5.49, \mathrm{La}_{2} \mathrm{O}_{3} 2.78, \mathrm{Ce}_{2} \mathrm{O}_{3}$ 14.04, $\mathrm{Pr}_{2} \mathrm{O}_{3} 3.28, \mathrm{Nd}_{2} \mathrm{O}_{3} 19.27, \mathrm{Sm}_{2} \mathrm{O}_{3} 5.30, \mathrm{Eu}_{2} \mathrm{O}_{3}$ $0.24, \mathrm{Gd}_{2} \mathrm{O}_{3} 4.10, \mathrm{~Tb}_{2} \mathrm{O}_{3} 0.36, \mathrm{Dy}_{2} \mathrm{O}_{3} 1.32, \mathrm{Ho}_{2} \mathrm{O}_{3} 0.18, \mathrm{Er}_{2} \mathrm{O}_{3} 0.38, \mathrm{MgO} 0.51, \mathrm{CaO} 0.14, \mathrm{MnO} 0.10, \mathrm{FeO}$ $10.62, \mathrm{~B}_{2} \mathrm{O}_{3} 0.10, \mathrm{BeO}_{\text {calc. }} 8.99, \mathrm{H}_{2} \mathrm{O}_{\text {calc. }} 0.55$ and total 99.52 giving the following empirical formula (based on $2 \mathrm{Si}$ ): $\left(\mathrm{Nd}_{0.632} \mathrm{Ce}_{0.472} \mathrm{Y}_{0.268} \mathrm{Sm}_{0.168} \mathrm{Gd}_{0.125} \mathrm{Pr}_{0.110} \mathrm{La}_{0.094} \mathrm{Dy}_{0.039} \mathrm{Ca}_{0.014} \mathrm{Er}_{0.011} \mathrm{~Tb}_{0.011} \mathrm{Eu}_{0.008}\right.$ $\left.\mathrm{Ho}_{0.008}\right)_{\sum 1.957}\left(\mathrm{Fe}_{0.816} \mathrm{Mg}_{0.070} \mathrm{Mn}_{0.008}\right)_{\sum 0.894}\left(\mathrm{Be}_{1.984} \mathrm{~B}_{0.016}\right)_{\sum 2.000} \mathrm{Si}_{2} \mathrm{O}_{9.660} \mathrm{OH}_{0.337}$. A weak Raman vibration band at $\sim 3525 \mathrm{~cm}^{-1}$ confirms the presence of water in the structure. Gadolinite-(Nd) is monoclinic, $P 2_{1} / c$, with $a=4.8216(3) \AA, b=7.6985(4) \AA, c=10.1362(6) \AA, \beta=90.234(4)^{\circ}, V=376.24(6) \AA^{3}$ and $Z=2$. The strongest X-ray diffraction lines are $\left[d_{\text {obs }}\right.$ in $\left.\AA(h k l) I_{\text {rel }}\right]: 4.830$ (100) 72, 3.603 (021) 37, 3.191(1112) 52, 3.097 (013) 35, 2.888 (121) 100, 2.607(113) 49, 2.412 (200) 24. Along with the Malmkärra mine, gadolinite(Nd) was also recorded also at Johannagruvan and Nya Bastnäs. The minerals of the gadolinite subgroup together with fluorbritholite-(Ce) incorporate the highest fraction of medium-to-heavy rare-earth elements among associated rare-earth element minerals in the Malmkärra mine and possibly in all Bastnäs-type deposits.

*E-mail:rskoda@sci.muni.cz https://doi.org/10.1180/minmag.2017.081.047
KEYWoRDs: gadolinite-(Nd), rare-earth elements, new mineral, crystal structure, Malmkärra, Bastnästype deposits.

This paper is part of a special issue entitled 'Critical-metal mineralogy and ore genesis'. The Geological Survey of Sweden (SGU) has contributed to the costs of Open Access publication for this paper. 


\section{Introduction}

THE mineral gadolinite has a special place in the history of science, and specifically so in chemistry and mineralogy. It was the study of what was then called "ytterbite" from the Ytterby pegmatite north of Stockholm, Sweden, by the Finnish-Swedish chemist Johan Gadolin (1760-1852), that led to the first discovery of a rare-earth element (REE) in the form of "yttria" (Gadolin, 1794). Gadolin's yttria was later proven to be a mixture of REEs, dominated by yttrium, while the "ytterbite" was finally named gadolinite (Ekeberg, 1802), now gadolinite-(Y). Presently, the REEs are very high on the European Union's lists of critical metals (http:// europa.eu/rapid/press-release_IP-14-599_en.htm) and neodymium is the most in demand. Systematic research towards the understanding of $R E E$ oreforming processes, a better knowledge of the distribution of these metals among the individual ore minerals, and the origin of these metals is of increasing interest.

The newly-defined gadolinite supergroup (Bačík et al., 2017) includes silicates, phosphates and arsenates with the general formula $A_{2} M Q T_{2} O_{8} \varphi_{2}$, where the individual structural sites are occupied as follows $A$ : $\mathrm{Ca}, R E E(\mathrm{Y}+$ lanthanoids $)>\mathrm{U}, \mathrm{Th}, \mathrm{Pb}$, $\mathrm{Mn}^{2+}$ and $\mathrm{Bi} ; M: \mathrm{Fe}^{2+}, \square$ (vacancy) $>\mathrm{Mg}, \mathrm{Mn}^{2+}$, $\mathrm{Zn}, \mathrm{Cu}, \mathrm{Al} ; Q$ : $\mathrm{Be}, \mathrm{B}>\mathrm{Li} ; \mathrm{T}$ : Si > P, As, B, Be, S; $\varphi$ : $\mathrm{O}, \mathrm{OH}>\mathrm{F}$ (Bačík et al., 2017). Based on the $T$-site occupancy, the gadolinite supergroup is divided into the gadolinite $\left[\mathrm{Si}^{4+}>\left(\mathrm{P}^{5+}+\mathrm{As}^{5+}\right)\right]$ and herderite $\left[\left(\mathrm{P}^{5+}+\mathrm{As}^{5+}\right)>\mathrm{Si}^{4+}\right]$ groups. Moreover, there are two subgroups within the gadolinite group, of which the gadolinite subgroup is dominated by $R E E^{3+}$ cations, and the datolite subgroup is dominated by divalent cations, in the $A$ site. Accordingly, the $Q$-site is occupied predominantly by $\mathrm{Be}^{2+}$ in the gadolinite subgroup and by $\mathrm{B}^{3+}$ in the datolite subgroup. The herderite group is also subdivided into the herderite and drugmanite subgroups (cf. Table 1).

Gadolinite-subgroup minerals (particularly gadolinite and hingganite) typically occur in rather metaluminous, fractionated granitic pegmatites with a NYF (Niobium-Yttrium-Fluorine; in the sense of Černý, 1991) signature (e.g. Bjørlykke, 1935; Brotzen, 1959; Haynes, 1965; Vorma et al., 1966; Nilssen, 1973; Bergstøl and Juve, 1988; Smeds, 1990; Kjellman et al., 1999; Pezzotta et al., 1999; Miyawaki et al., 2007; Škoda et al., 2012, 2015; Pieczka et al., 2015), alkaline rocks (e.g. Segalstad and Larsen, 1978; Cámara et al., 2008; Pekov et al., 2007; Lyalina et al., 2014), REE-rich
TABLE 1. Minerals of the gadolinite supergroup and their structural formulae (Bačík et al., 2017).

$\begin{array}{ll}\begin{array}{l}\text { Gadolinite group } \\ \text { Datolite subgroup } \\ \text { Datolite }\end{array} & \\ \text { Homilite } & \mathrm{Ca}_{2} \square \mathrm{B}_{2} \mathrm{Si}_{2} \mathrm{O}_{8}(\mathrm{OH})_{2} \\ \text { Gadolinite subgroup } & \mathrm{Ca}_{2} \mathrm{Fe}^{2+} \mathrm{B}_{2} \mathrm{Si}_{2} \mathrm{O}_{10} \\ \text { Gadolinite-(Ce) } & \mathrm{Ce}_{2} \mathrm{Fe}^{2+} \mathrm{Be}_{2} \mathrm{Si}_{2} \mathrm{O}_{10} \\ \text { Gadolinite-(Nd) } & \mathrm{Ne}_{2} \mathrm{Fe}^{2+} \mathrm{Be}_{2} \mathrm{Si}_{2} \mathrm{O}_{10} \\ \text { Gadolinite-(Y) } & \mathrm{Y}_{2} \mathrm{Fe}^{2+} \mathrm{Be}_{2} \mathrm{Si}_{2} \mathrm{O}_{10} \\ \text { Hingganite-(Ce) } & \mathrm{Ce}_{2} \square \mathrm{Be}_{2} \mathrm{Si}_{2} \mathrm{O}_{8}(\mathrm{OH})_{2} \\ \text { Hingganite-(Y) } & \mathrm{Y}_{2} \square \mathrm{Be}_{2} \mathrm{Si}_{2} \mathrm{O}_{8}(\mathrm{OH})_{2} \\ \text { Hingganite-(Yb) } & \mathrm{Yb}_{2} \square \mathrm{Be}_{2} \mathrm{Si}_{2} \mathrm{O}_{8}(\mathrm{OH})_{2} \\ \text { Minasgeraisite-(Y) } & \mathrm{Y}_{2} \mathrm{CaBe}_{2} \mathrm{Si}_{2} \mathrm{O}_{10} \\ \text { Herderite group } & \\ \text { Drugmanite subgroup } & \\ \text { Drugmanite } & \mathrm{Pb}_{2} \mathrm{Fe}^{3+} \square \mathrm{P}_{2}\left[\mathrm{O}_{7}(\mathrm{OH})\right](\mathrm{OH})_{2} \\ \text { Herderite subgroup } & \mathrm{Ca}_{2} \square \mathrm{Be}_{2} \mathrm{As}_{2} \mathrm{O}_{8}(\mathrm{OH})_{2} \\ \text { Bergslagite } & \mathrm{Ca}_{2} \square \mathrm{Be}_{2} \mathrm{P}_{2} \mathrm{O}_{8} \mathrm{~F}_{2} \\ \text { Herderite } & \mathrm{Ca}_{2} \square \mathrm{Be}_{2} \mathrm{P}_{2} \mathrm{O}_{8}(\mathrm{OH})_{2} \\ \text { Hydroxylherderite } & \\ \end{array}$

Alpine-type hydrothermal mineralizations (e.g. Demartin et al., 1993; Bonazzi et al., 2003; Pršek et al., 2010), and some iron-oxide skarn deposits (e.g. Geijer, 1961; Holtstam and Andersson, 2007).

The members of the gadolinite subgroup with a magmatic origin are commonly metamict due to significant amounts of actinides substituting for $R E E$, which complicates their structural investigation. Well-crystalline samples are scarce and usually of a hydrothermal origin (Demartin et al., 1993).

A neodymium-dominant analogue of gadolinite(Y) or gadolinite-(Ce) was suggested by Holtstam and Andersson (2007) from Bastnäs-type skarn deposits (Bergslagen ore province, south-central Sweden), but due to the lack of a sufficient amount of material, they did not provide any data apart from the chemical microanalyses. This paper provides a full characterization, including chemical composition, structural, physical and optical properties of the new mineral gadolinite-(Nd), which was approved recently by the Commission on New Minerals, Nomenclature and Classification (CNMNC) of the International Mineralogical Association (IMA), under the number 2016-013. The name is given in analogy with the other members of the gadolinite subgroup (Bačík et al., 2017), as the neodymiumdominant species. Type material is deposited under catalogue number B 11298 at the Moravian Museum, Brno, Czech Republic. 


\section{Geological setting and the type locality}

Gadolinite-(Nd) was found in samples from the Malmkärra, Johanna and Nya Bastnäs mines, all belonging to the Fe-REE 'Bastnäs-type' skarn deposits in the Bergslagen ore province (Geijer, 1961; Holtstam and Andersson, 2007; Jonsson et al., 2014; Holtstam et al., 2014). The present mineral characterization was only undertaken on material from the Malmkärra mine $\left(60^{\circ} 4^{\prime} \mathrm{N}, 15^{\circ} 51^{\prime}\right.$ E), $\sim 3.5 \mathrm{~km} \mathrm{WSW} \mathrm{of} \mathrm{Norberg} \mathrm{due} \mathrm{to} \mathrm{the} \mathrm{very} \mathrm{small}$ size of gadolinite-(Nd) crystals $(<30 \mu \mathrm{m})$ at the other localities.

The Bastnäs-type deposits occur in the northwestern part of the Bergslagen ore province, south central Sweden, in the so-called 'REE-line' (Jonsson and Högdahl, 2013; Goodenough et al., 2016). This is an over $100 \mathrm{~km}$ long, north-easttrending, narrow belt within Svecofennian (1.91$1.88 \mathrm{Ga})$, mainly felsic metavolcanic rocks with discontinuous, interlayered carbonate (marble) horizons. The volcanic sequences were intensively metasomatized at the synvolcanic stage, and much of the carbonates have been replaced by skarn, hosting the localized Fe-REE mineralizations. The skarn-hosted Fe-oxide- $R E E$-polymetallic mineralization at Bastnäs, in the central part of the REEline, has been dated from the Re-Os contents of molybdenite to give ages between 1.90 and $1.84 \mathrm{Ga}$. The mineralization is suggested to be the products of reactions between carbonate interlayers with $\mathrm{Si}, \mathrm{F}, \mathrm{Cl}, \mathrm{S}, \mathrm{CO}_{2}$ and $R E E$-bearing, hightemperature fluids of a magmatic origin (Holtstam et al., 2014; Sahlström et al., 2015). The term
'Bastnäs-type deposits' was introduced by Geijer (1961) to characterize a group of similar, $\mathrm{Fe}+\mathrm{REE}$ $\pm \mathrm{Cu} \pm \mathrm{Mo} \pm \mathrm{Bi} \pm \mathrm{Au}$ mineralized skarns that supposedly have a common origin to the Nya Bastnäs deposit. Based mainly on differences in mineral assemblages, Holtstam and Andersson (2007) divided them into two subtypes: deposits of subtype 1 are essentially only enriched in lightrare-earth elements (LREE), whereas those of subtype 2 are enriched in both light and heavyrare-earth elements (LREE and HREE, respectively).

The Malmkärra deposit (subtype 2) is hosted by a partly dolomitic marble that forms a conformable interlayer within the surrounding, typically extensively altered metavolcanic rocks. The skarn ore body, formed through reactions and replacement of parts of the carbonate interlayer, occurs along the contact with the more extensively altered metavolcanic rocks. Magnetite is the sole ore mineral that was mined, and tremolitic amphibole, humitegroup minerals, commonly serpentine-altered, biotite and phlogopite make up the main skarn silicates; sulfide minerals (pyrite, chalcopyrite and molybdenite) are locally present as well (Geijer, 1936). Allanites sensu lato represent the most widespread REE minerals scattered in the skarn, as well as in the iron ore. During mining, a $\sim 0.5 \mathrm{~m}$ thick zone of massive $R E E$ silicates [dominated by fluorbritholite-(Ce), västmanlandite-(Ce) and dollaseite-(Ce)] was encountered in the deeper levels of the mine, along the contact between the marble and the skarn iron ore (Geijer, 1936; Andersson, 2004). The REE minerals reported from the Malmkärra mine are summarized in Table 2.

TABLE 2. List of REE-minerals from the Malmkärra mine, after Holtstam and Andersson (2007), Holtstam et al. (2005).

\begin{tabular}{|c|c|}
\hline Mineral & Formula \\
\hline Allanite-(Ce) & $(\mathrm{Ce}, \mathrm{La}) \mathrm{CaFe}^{2+} \mathrm{Al}_{2}\left[\mathrm{Si}_{2} \mathrm{O}_{7}\right]\left[\mathrm{SiO}_{4}\right] \mathrm{O}(\mathrm{OH})$ \\
\hline Bastnäsite-(Ce) & $(\mathrm{Ce}, \mathrm{La}) \mathrm{CO}_{3} \mathrm{~F}$ \\
\hline Cerite-(Ce) & $(\mathrm{Ce}, \mathrm{La}, \mathrm{Nd})_{9}(\mathrm{Mg}, \mathrm{Fe}) \mathrm{Si}_{7} \mathrm{O}_{24}(\mathrm{O}, \mathrm{OH}, \mathrm{F})_{7}$ \\
\hline Dissakisite-(Ce) & $\mathrm{Ca}(\mathrm{Ce}, \mathrm{La}) \mathrm{MgAl}_{2}\left[\mathrm{Si}_{2} \mathrm{O}_{7}\right]\left[\mathrm{SiO}_{4}\right] \mathrm{O}(\mathrm{OH})$ \\
\hline Dollaseite-(Ce) & $\mathrm{Ca}(\mathrm{Ce}, \mathrm{La}) \mathrm{Mg}_{2} \mathrm{Al}\left[\mathrm{Si}_{2} \mathrm{O}_{7}\right]\left[\mathrm{SiO}_{4}\right] \mathrm{F}(\mathrm{OH})$ \\
\hline Fluorbritholite-(Ce) & $(\mathrm{Ce}, \mathrm{Ca})_{5}\left[\mathrm{SiO}_{4}\right]_{3} \mathrm{~F}$ \\
\hline Gadolinite-(Ce) & $\mathrm{Ce}_{2} \mathrm{Fe}^{2+} \mathrm{Be}_{2} \mathrm{Si}_{2} \mathrm{O}_{10}$ \\
\hline Gadolinite-(Nd) & $\mathrm{Nd}_{2} \mathrm{Fe}^{2+} \mathrm{Be}_{2} \mathrm{Si}_{2} \mathrm{O}_{10}$ \\
\hline Gadolinite-(Y) & $\mathrm{Y}_{2} \mathrm{Fe}^{2+} \mathrm{Be}_{2} \mathrm{Si}_{2} \mathrm{O}_{10}$ \\
\hline Magnesiorowlandite-(Y) & $(\mathrm{Y}, R E E)_{4} \mathrm{MgSi}_{4} \mathrm{O}_{14} \mathrm{~F}_{2}$ \\
\hline Västmanlandite-(Ce) & $\mathrm{Ca}(\mathrm{Ce}, \mathrm{La})_{3} \mathrm{Al}_{2} \mathrm{Mg}_{2}\left[\mathrm{Si}_{2} \mathrm{O}_{7}\right]\left[\mathrm{SiO}_{4}\right]_{3} \mathrm{~F}(\mathrm{OH})_{2}$ \\
\hline
\end{tabular}


The Malmkärra iron mine has a long history. The oldest preserved record is from 1664, with major mining operations taking place from 1885 up to its final closure in 1936 (Geijer and Magnusson, 1944; Andersson, 2004). Malmkärra is also the type locality of västmanlandite-(Ce), see Holtstam et al. (2005).

\section{Results}

\section{Mineral association, appearance and physical properties}

The skarn rock sample $(\sim 10 \mathrm{~cm} \times 10 \mathrm{~cm} \times 5 \mathrm{~cm})$ containing gadolinite-(Nd) was found on the dumps of the Malmkärra mine. Gadolinite-(Nd) forms anhedral grains up to $150 \mu \mathrm{m}$ in size, occurring as aggregates associated with tremolite, dollaseite$(\mathrm{Ce})$, västmanlandite-(Ce), fluorbritholite-(Ce) and bastnäsite-(Ce) (Fig. 1). Gadolinite-(Nd) is transparent and, under the optical microscope in thin section, it is pale olive green, while larger fragments are olive green. It has a white streak and a vitreous to adamantine lustre. No visible fluorescence under shortwave or longwave ultraviolet light was observed. The Mohs hardness is between 6.5 and 7. Gadolinite-(Nd) is brittle with a conchoidal fracture; no cleavage or parting was observed. The density $\left(D_{\text {calc }}\right)$ is $4.86 \mathrm{~g} \mathrm{~cm}^{-3}$, and was calculated using the empirical formula and unit-cell parameters obtained from the single-crystal X-ray diffraction (XRD) data. A density measurement could not be performed directly due to the lack of suitable material. Optically, gadolinite-(Nd) is weakly pleochroic in shades of olive green, biaxial $(-), \mathrm{n}_{\alpha}=1.78(1), \mathrm{n}_{\beta(\text { calc. })}=1.80, \mathrm{n}_{\gamma}=$ 1.81(1) measured in white light. The poor optical quality of the measured fragments did not allow more precise determination of the refractive indices. The angle of the optical axes, $2 \mathrm{~V}_{\text {(meas.) }}: 62(3)^{\circ}$ was
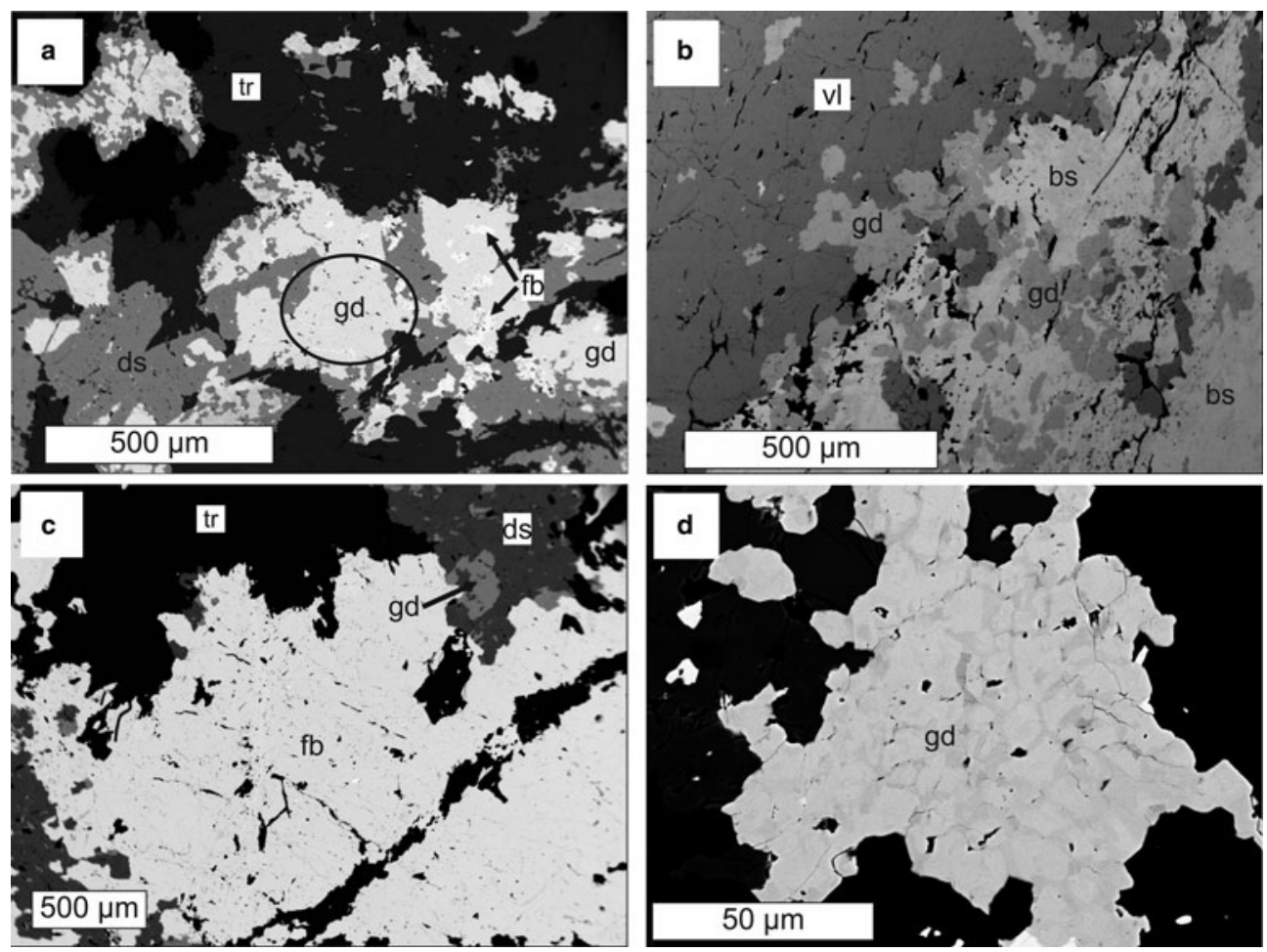

FIG. 1. Back-scattered electron images of gadolinite-(Nd) and associated REE minerals from $(a-c)$ Malmkärra and $(d)$ Johannagruvan. gd-gadolinite-(Nd), ds-dollaseite-(Ce), fb-fluorbritholite-(Ce), tr-tremolite, vl-västmanlandite-(Ce), bsbastnäsite-(Ce). The aggregate from which the crystals for single-crystal X-ray diffraction and optical study were extracted is indicated by an ellipse. The zoning of the gadolinite-(Nd) from Johannagruvan $(d)$ reflects Y-lanthanoids variability; the Y-rich zones are darker. 
TABLE 3. Chemical composition of the gadolinite-(Nd) based on the EMP and LA-ICP-MS data.

\begin{tabular}{|c|c|c|c|c|c|c|}
\hline Constituent & Mean $^{+}$ & Range $^{\S}$ & Det. limit. ${ }^{\phi}$ & Constituent & $\mathrm{apfu}^{+}$ & Probe standard; X-ray line \\
\hline $\mathrm{SiO}_{2}$ & 21.77 & $21.59-22.27$ & 0.04 & $\mathrm{Si}$ & 2.000 & sanidine, $K \alpha$ \\
\hline $\mathrm{Y}_{2} \mathrm{O}_{3}$ & 5.49 & $3.60-5.83$ & 0.05 & $\mathrm{Y}$ & 0.268 & YAG, $L \alpha$ \\
\hline $\mathrm{La}_{2} \mathrm{O}_{3}$ & 2.78 & $2.04-3.08$ & 0.12 & $\mathrm{La}$ & 0.094 & $\mathrm{LaPO}_{4}, L \alpha$ \\
\hline $\mathrm{Ce}_{2} \mathrm{O}_{3}$ & 14.04 & $11.77-14.3$ & 0.13 & $\mathrm{Ce}$ & 0.472 & $\mathrm{CePO}_{4}, L \alpha$ \\
\hline $\mathrm{Pr}_{2} \mathrm{O}_{3}$ & 3.28 & $3.12-3.79$ & 0.16 & $\operatorname{Pr}$ & 0.110 & $\mathrm{PrPO}_{4}, L \beta$ \\
\hline $\mathrm{Nd}_{2} \mathrm{O}_{3}$ & 19.27 & $18.88-22.04$ & 0.17 & $\mathrm{Nd}$ & 0.632 & $\mathrm{NdPO}_{4}, L \beta$ \\
\hline $\mathrm{Sm}_{2} \mathrm{O}_{3}$ & 5.30 & $5.04-6.08$ & 0.17 & $\mathrm{Sm}$ & 0.168 & $\mathrm{SmPO}_{4}, L \beta$ \\
\hline $\mathrm{Eu}_{2} \mathrm{O}_{3}$ & 0.24 & $0.16-0.28$ & 0.12 & $\mathrm{Eu}$ & 0.008 & $\mathrm{EuPO}_{4}, L \beta$ \\
\hline $\mathrm{Gd}_{2} \mathrm{O}_{3}$ & 4.10 & $3.60-4.43$ & 0.18 & $\mathrm{Gd}$ & 0.125 & $\mathrm{GdPO}_{4}, L \beta$ \\
\hline $\mathrm{Tb}_{2} \mathrm{O}_{3}$ & 0.36 & $0.31-0.43$ & 0.11 & $\mathrm{~Tb}$ & 0.011 & $\mathrm{TbPO}_{4}, L \alpha$ \\
\hline $\mathrm{Dy}_{2} \mathrm{O}_{3}$ & 1.32 & $1.05-1.52$ & 0.12 & Dy & 0.039 & $\mathrm{DyPO}_{4}, L \beta$ \\
\hline $\mathrm{Ho}_{2} \mathrm{O}_{3}$ & 0.18 & $0.11-0.21$ & 0.11 & Но & 0.005 & $\mathrm{HoPO}_{4}, L \beta$ \\
\hline $\mathrm{Er}_{2} \mathrm{O}_{3}$ & 0.38 & $0.18-0.38$ & 0.12 & $\mathrm{Er}$ & 0.011 & $\mathrm{ErPO}_{4}, L \alpha$ \\
\hline $\mathrm{MgO}$ & 0.51 & $0.40-0.92$ & 0.04 & $\mathrm{Mg}$ & 0.070 & pyrope, $K \alpha$ \\
\hline $\mathrm{CaO}$ & 0.14 & $0.14-0.24$ & 0.03 & $\mathrm{Ca}$ & 0.014 & wollastonite, $K \alpha$ \\
\hline $\mathrm{MnO}$ & 0.10 & $0.10-0.20$ & 0.06 & $\mathrm{Mn}$ & 0.008 & spessartine, $K \alpha$ \\
\hline $\mathrm{FeO}$ & 10.62 & $10.09-10.93$ & 0.07 & $\mathrm{Fe}$ & 0.816 & almandine, $K \alpha$ \\
\hline $\mathrm{BeO} *$ & 8.99 & & & $\mathrm{Be}$ & 1.984 & \\
\hline $\mathrm{B}_{2} \mathrm{O}_{3} * *$ & 0.10 & $0.06-0.13$ & 0.02 & B & 0.016 & NIST 610 \\
\hline $\mathrm{H}_{2} \mathrm{O}^{\$}$ & 0.55 & & & $\mathrm{OH}$ & 0.337 & \\
\hline \multirow[t]{3}{*}{ Total } & 99.52 & & & $\mathrm{O}$ & 9.660 & \\
\hline & & & & $\Sigma R E E$ & $\overline{1.957}$ & \\
\hline & & & & $M$-site vac. & 0.106 & \\
\hline
\end{tabular}

${ }^{+}$Mean of three analyses of the crystal used for structural determination; apfu=atoms per formula unit; *determined from stoichiometry; ${ }^{\$}$ range of all (11) analyses; ${ }^{* *}$ measured by LA-ICP-MS; ${ }^{\phi}$ detection limit in oxides; ${ }^{\$}$ calculated from charge balance.

measured using extinction by means of a spindle stage and computed by the EXCALIBR II software. Dispersion is strong $(r<v)$.

\section{Composition}

The compositions of gadolinite-(Nd) and associated minerals were determined by means of electron-probe microanalysis (EPMA) with a CAMECA SX100 in wavelength-dispersive mode at an accelerating voltage of $15 \mathrm{kV}$, a beam current $20 \mathrm{nA}$ and a beam diameter of $5 \mu \mathrm{m}$. The standards, $\mathrm{X}$-ray lines and monochromators used for analysis are listed in Table 2. Aluminium, $\mathrm{Pb}, \mathrm{Tm}, \mathrm{Yb}$ and $\mathrm{Lu}$ were also analysed for, but their contents were below the detection limit. The peak counting times varied from $10 \mathrm{~s}$ for the main elements to $60 \mathrm{~s}$ for the minor elements and high and low energy background was counted for $1 / 2$ of the peak counting time of the relevant analytical line. The raw data were processed using the $\mathrm{X}$-phi matrix correction routine (Merlet, 1994). Based on the counting statistics, the measurement error expressed as $2 \sigma$ is approximately $<1$ rel. $\%$ for concentrations of $\sim 20$ wt. $\%$ and $\sim 8$ rel. $\%$ for concentrations of $\sim 1=$ wt. $\%$.

The contents of $\mathrm{Be}, \mathrm{B}$ and other trace elements below the detection limit of the EPMAwere sought for by means of an Agilent 7500ce quadrupole Inductively Coupled Plasma Mass Spectrometer (ICP-MS; Agilent 7500ce, Santa Clara, CA, USA) with an attached UP 213 laser ablation (LA) system (New Wave Research, Inc., Fremont, CA, USA). The LA-ICP-MS system consists of a nanosecond laser Nd:YAG operating at $213 \mathrm{~nm}$ (pulse duration of $4.2 \mathrm{~ns}$ ) and a SuperCell ablation chamber. Ablated material was transported from the sample chamber using helium carrier gas $\left(1 \mathrm{~L} \mathrm{~min}^{-1}\right)$ and mixed with argon $\left(0.6 \mathrm{~L} \mathrm{~min}^{-1}\right)$ prior to the torch. Potential polyatomic interferences were minimized by a collision reaction cell in He mode $\left(1 \mathrm{~mL} \mathrm{~min}^{-1}\right)$. The contents of major to trace elements were determined after laser ablation of individual spots at the following conditions: diameter $55 \mu \mathrm{m}$, strength of laser beam $4 \mathrm{~J} \mathrm{~cm}^{-2}$, frequency $10 \mathrm{~Hz}$ and spot 
TABLE 4. LA-ICP-MS data for gadolinite-(Nd) from Malmkärra (in ppm).

\begin{tabular}{lccc}
\hline & Mean, $n=9$ & Range & Stand. Dev. \\
\hline $\mathrm{Be}$ & 36,400 & $31,300-39,700$ & 2530 \\
$\mathrm{~B}$ & 301 & $174-393$ & 61 \\
$\mathrm{Y}$ & 28,200 & $21,000-35,900$ & 5500 \\
$\mathrm{La}$ & 35,000 & $24,800-43,100$ & 7520 \\
$\mathrm{Ce}$ & 142,200 & $123,900-167,600$ & 13,540 \\
$\mathrm{Pr}$ & 32,500 & $27,900-39,600$ & 3670 \\
$\mathrm{Nd}$ & 208,200 & $176,100-255,700$ & 27,890 \\
$\mathrm{Sm}$ & 40,200 & $31,500-54,400$ & 7360 \\
$\mathrm{Eu}$ & 2050 & $1560-2770$ & 342 \\
$\mathrm{Gd}$ & 26,700 & $21,400-31,900$ & 3410 \\
$\mathrm{~Tb}$ & 2560 & $1690-3330$ & 508 \\
$\mathrm{Dy}$ & 8920 & $5730-13,400$ & 2190 \\
$\mathrm{Ho}$ & 901 & $629-1310$ & 204 \\
$\mathrm{Er}$ & 1730 & $1180-2340$ & 359 \\
$\mathrm{Tm}$ & 102 & $66-162$ & 26 \\
$\mathrm{Yb}$ & 619 & $351-10,600$ & 195 \\
$\mathrm{Lu}$ & 58 & $32-97$ & 17 \\
$\mathrm{Th}$ & 3.7 & $1.8-5.6$ & 1 \\
$\mathrm{U}$ & 83 & $45-152$ & 32 \\
& & & \\
\hline
\end{tabular}

ablation time $30 \mathrm{~s}$. The contents of elements of interest were determined using SRM NIST 610 and ${ }^{28} \mathrm{Si}$ for internal calibration and the calculations were performed via peak area of isotopes.

The empirical formula has been calculated on the basis of 2 atoms per formula unit of Si and the amount of $\mathrm{OH}$ has been charge balanced to keep the empirical formula electroneutral.

The composition of gadolinite-(Nd) was examined from three thin sections prepared from a single piece of the massive $R E E$-silicate-rich sample. The gadolinite shows quite variable chemical composition, particularly in the REE pattern and the $\mathrm{Y} /$ $(R E E)$ ratio, but all analyses $(n=11)$ are $\mathrm{Nd}$ dominant and correspond to gadolinite-(Nd), see Table 3. The calcium content is low (0.140.24 wt.\% $\mathrm{CaO}$ ). Holtstam and Andersson (2007) performed Mössbauer spectroscopy on the gadolinite- $(\mathrm{Ce} / \mathrm{Y})$ from Malmkärra, which revealed the presence of exclusively divalent $\mathrm{Fe}$. Therefore, all $\mathrm{Fe}$ is assumed as divalent in gadolinite-(Nd). Apart from $\mathrm{Fe}$, the $M$ site is occupied by $\mathrm{Mg}(0.51-0.66$ wt.\% $\mathrm{MgO}$ ) and $\mathrm{Mn}$ (0.10-0.14 wt.\% MnO). All these cations do not fill the $M$ site completely, thus a minor vacancy (0.093-0.143 $\square \mathrm{pfu})$ is present. Seven grains, previously analysed by EPMA, were subsequently analysed by LA-ICP-MS to determine the Be and
B content as well as the whole suite of the REEs and some trace elements (Table 4). A chondritenormalized REE pattern (using a combination of EPMA and LA-ICP-MS data) shows the maxima at $\mathrm{Nd}$ and depletion of the lightest and heavy REE as well as a moderate Eu anomaly $\left(\mathrm{Eu}_{\mathrm{N}} * / \mathrm{Eu}_{\mathrm{N}}=\right.$ 0.16), see Fig. 2. The content of $\mathrm{BeO}$ obtained from the LA-ICP-MS analysis ranges from 8.69 to 11.02 wt. $\%$ with a mean of 10.11 wt. $\%$. The theoretical $\mathrm{BeO}$ content, calculated from stoichiometry, is $\sim 9.0$ wt. $\%$. This discrepancy, $\sim 10$ rel. $\%$, is still within the analytical error of LA-ICP-MS for $\mathrm{Be}\left(\sim 10\right.$ rel.\%). The average content of $\mathrm{B}_{2} \mathrm{O}_{3}$ is 0.10 wt.\%. Laser ablation ICP-MS also revealed very low $\mathrm{U}$ and $\mathrm{Th}$ contents in the gadolinite $(\sim 80$ and $\sim 5 \mathrm{ppm}$, respectively). Such a low radioactive element content does not affect the crystallinity of the mineral. A small amount of $\mathrm{OH}(0.34 \mathrm{pfu})$ resulted from the calculation of an empirical formula. The empirical formula obtained from the mean of three analyses of the crystal used for structural determination is:

$$
\begin{aligned}
& \left(\mathrm{Nd}_{0.632} \mathrm{Ce}_{0.472} \mathrm{Y}_{0.268} \mathrm{Sm}_{0.168} \mathrm{Gd}_{0.125} \mathrm{Pr}_{0.110} \mathrm{La}_{0.094}\right. \\
& \left.\mathrm{Dy}_{0.039} \mathrm{Ca}_{0.014} \mathrm{Er}_{0.011} \mathrm{~Tb}_{0.011} \mathrm{Eu}_{0.008} \mathrm{Ho}_{0.008}\right)_{\Sigma 1.957} \\
& \left(\mathrm{Fe}_{0.816} \mathrm{Mg}_{0.070} \mathrm{Mn}_{0.008}\right)_{\Sigma 0.894}\left(\mathrm{Be}_{1.984} \mathrm{~B}_{0.016}\right)_{\Sigma 2.000} \\
& \mathrm{Si}_{2} \mathrm{O}_{9.660} \mathrm{OH}_{0.337}
\end{aligned}
$$

The ideal formula is $\mathrm{Nd}_{2} \mathrm{FeBe}_{2} \mathrm{Si}_{2} \mathrm{O}_{10}$, which requires 58.16 wt.\% $\mathrm{Nd}_{2} \mathrm{O}_{3}, 12.42$ wt.\% $\mathrm{FeO}$, 8.65 wt. $\% \mathrm{BeO}$ and 20.77 wt. $\% \mathrm{SiO}_{2}$.

A part of the largest grain $(150 \mu \mathrm{m} \times 100 \mu \mathrm{m})$ of gadolinite-(Nd), carefully measured by EPMA, was extracted subsequently from the thin section for the single-crystal X-ray diffraction study. The other parts of this grain were used for determination of the optical properties.

\section{Raman spectroscopy}

Raman analysis of gadolinite-(Nd), performed on uncoated polished sections, was undertaken by means of a Horiba LabRAM HR Evolution spectrometer. This dispersive, edge-filter-based system was equipped with an Olympus BX 41 optical microscope, a diffraction grating with 600 grooves per millimetre, and a Peltier-cooled, Sibased charge-coupled device (CCD) detector. Raman spectra of REE-bearing minerals are commonly obscured by laser-induced emissions of the REE (e.g. Nasdala et al., 2012; Lenz et al., 2015). After careful tests with different lasers (473, 523 and $633 \mathrm{~nm})$, the $633 \mathrm{~nm} \mathrm{He}-\mathrm{Ne}$ laser $(10 \mathrm{~mW}$ 

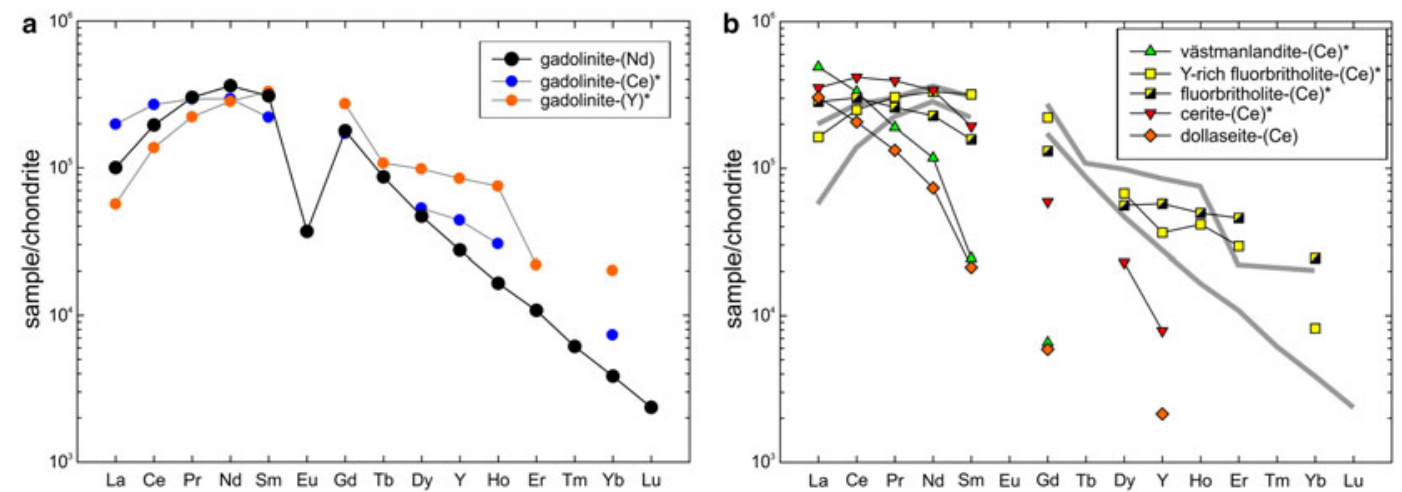

Fig. 2. (a) Chondrite-normalized REE pattern of gadolinite-(Nd) obtained as a combination of EPMA and LA-ICP-MS data. Patterns of gadolinite-(Ce) and gadolinite-(Y) from Holtstam and Andersson (2007) are plotted for comparison. (b) Patterns of other REE-silicates from Malmkärra are plotted for visualization of distribution of REE among individual structural types. Grey, thick, lines indicate the compositional field of gadolinite-subgroup minerals. Chondrite values of McDonough and Sun (1995) were used for normalization. Data for minerals indicated by an asterisk are taken from Holtstam and Andersson (2007).

at the sample surface) was selected for spectral acquisition to minimize analytical artefacts. With the Olympus $100 \times$ objective (numerical aperture 0.9 ) and the system being operated in the confocal mode, the lateral resolution was $\sim 1 \mu \mathrm{m}$. Wavenumber calibration was done using the Rayleigh line and Ne-lamp emissions. The wavenumber accuracy was $>0.5 \mathrm{~cm}^{-1}$ and the spectral resolution was $\sim 2 \mathrm{~cm}^{-1}$. Band fitting was done after appropriate background correction, assuming combined Lorentzian-Gaussian band shapes using PeakFit (Jandel Scientific Software).

The Raman spectrum of gadolinite-(Nd) is shown in Fig. 3. Following the spectroscopic

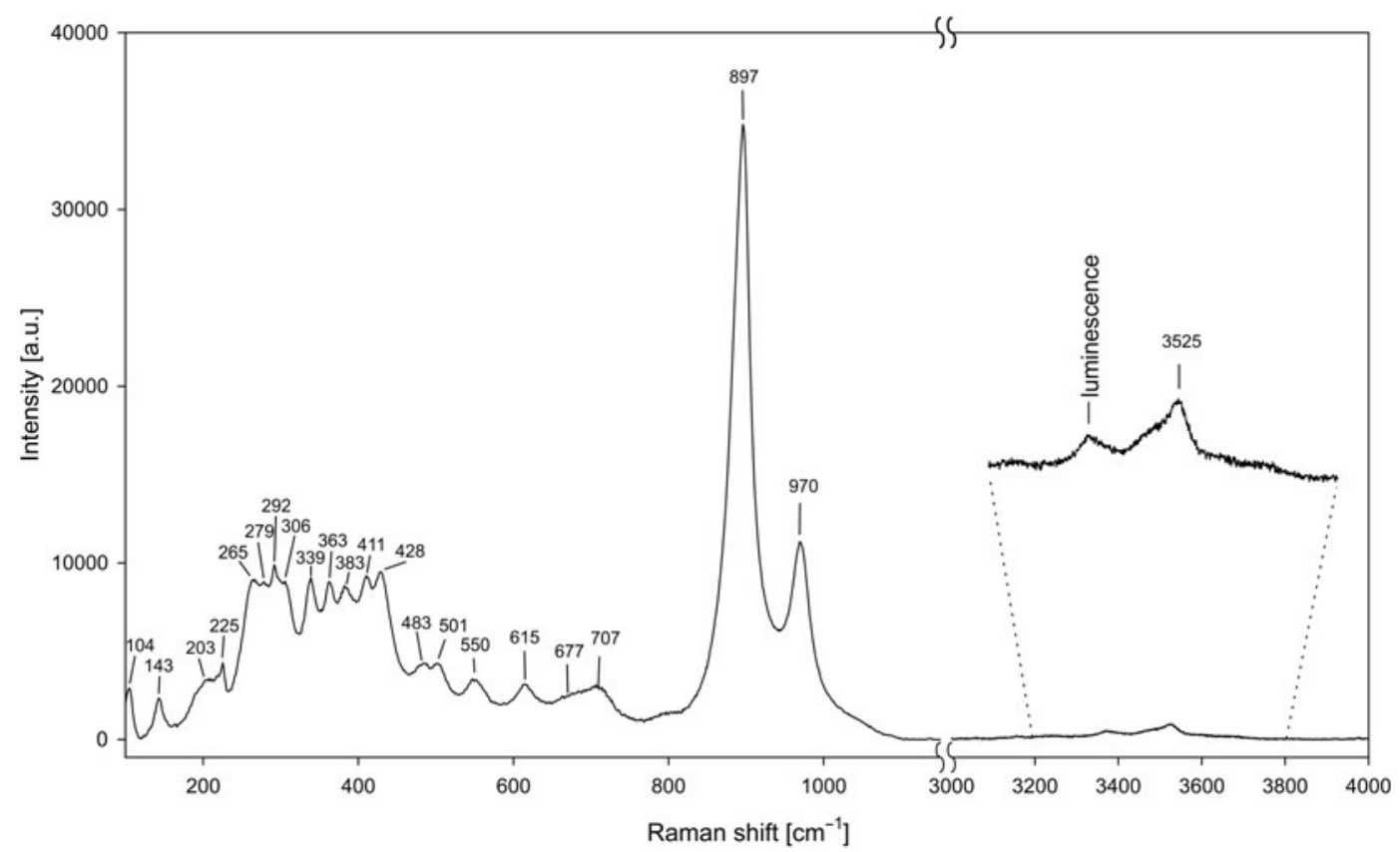

FIG. 3. Raman spectrum of gadolinite-(Nd) excited by a $633 \mathrm{~nm}$ laser. 
TABLE 5. Powder XRD data of gadolinite-(Nd) from Malmkärra.

\begin{tabular}{|c|c|c|c|c|c|c|c|c|c|c|}
\hline$\underline{I_{\text {obs. }}}$ & $d_{\text {obs. }}$ & $d_{\text {calc. }}$ & $I_{\text {calc. }}$ & $h k l$ & $I_{\text {obs. }}$ & $d_{\text {obs. }}$ & & $d_{\text {calc. }}$ & $I_{\text {calc. }}$ & $h k l$ \\
\hline 8 & 6.147 & 6.142 & 32 & 011 & 8 & 1.805 & & 1.806 & 13 & 034 \\
\hline 13 & 5.085 & 5.073 & 20 & 002 & $<5$ & 1.796 & & 1.803 & 12 & 042 \\
\hline 72 & 4.830 & 4.826 & 100 & 100 & 6 & 1.793 & & 1.796 & 14 & 025 \\
\hline 18 & 4.239 & 4.239 & 29 & 012 & $<5$ & 1.789 & & 1.791 & 19 & 140 \\
\hline$<5$ & 3.843 & 3.859 & 2 & 020 & $<5$ & & & 1.764 & 1 & $\overline{1} 41$ \\
\hline 10 & 3.798 & 3.798 & 11 & $\overline{1} 11$ & $<5$ & $1 . / 61$ & & 1.764 & 2 & 141 \\
\hline 7 & 3.776 & 3.792 & 13 & 111 & $<5$ & 1.756 & & 1.760 & $<1$ & 230 \\
\hline 37 & 3.603 & 3.607 & 79 & 021 & $<5$ & 1.734 & & 1.735 & 4 & $\overline{2} 31$ \\
\hline \multirow{2}{*}{13} & \multirow[b]{2}{*}{3.491} & 3.502 & 16 & $\overline{1} 02$ & $<5$ & 1.730 & & 1.733 & 2 & 231 \\
\hline & & 3.492 & 26 & 102 & \multirow[t]{2}{*}{6} & \multirow{2}{*}{1.704} & & 1.707 & 10 & $\overline{2} 14$ \\
\hline 52 & 3.191 & 3.189 & 55 & $\overline{1} 12$ & & & & 1.703 & 13 & 214 \\
\hline 32 & 3.179 & 3.181 & 48 & 112 & 13 & 1.690 & & 1.691 & 16 & 134 \\
\hline 35 & 3.097 & 3.098 & 55 & 013 & $<5$ & & & 1.685 & 9 & 125 \\
\hline 25 & 3.014 & 3.014 & 25 & 120 & $<$ & 1.082 & & 1.682 & 8 & 125 \\
\hline \multirow{2}{*}{100} & \multirow{2}{*}{2.888} & 2.890 & 73 & 121 & \multirow{2}{*}{8} & \multirow[b]{2}{*}{1.662} & & 1.664 & 15 & $\overline{2} 32$ \\
\hline & & 2.888 & 71 & 121 & & & & 1.662 & 15 & 232 \\
\hline \multirow{2}{*}{49} & \multirow{2}{*}{2.607} & 2.610 & 50 & 113 & 5 & 1.650 & & 1.652 & 0 & 016 \\
\hline & & 2.604 & 55 & 113 & $<5$ & 1.604 & & 1.609 & 7 & 300 \\
\hline 8 & 2.534 & 2.537 & 4 & 004 & 6 & 1.596 & & 1.597 & 11 & 106 \\
\hline 6 & 2.492 & 2.493 & 8 & 031 & $<5$ & 1.593 & & 1.595 & 11 & 106 \\
\hline \multirow{2}{*}{24} & \multirow{2}{*}{2.412} & 2.413 & 31 & 200 & $<5$ & 1.586 & & 1.594 & 1 & $\overline{2} 24$ \\
\hline & & 2.410 & 26 & 014 & $<5$ & 1.567 & & 1.564 & 0 & 116 \\
\hline 16 & 2.294 & 2.294 & 34 & 032 & \multirow{2}{*}{$<5$} & \multirow{2}{*}{1.554} & & 1.557 & 1 & $\overline{3} 11$ \\
\hline \multirow[t]{2}{*}{$<5$} & \multirow[t]{2}{*}{2.268} & 2.270 & 1 & 130 & & & l & 1.556 & 1 & 311 \\
\hline & & 2.248 & 3 & 123 & $<5$ & 1.548 & & 1.549 & 4 & 026 \\
\hline \multirow{3}{*}{11} & & 2.248 & $<1$ & 104 & $<5$ & 1.533 & & 1.535 & 1 & $\overline{3} 02$ \\
\hline & 2.248 & 2.247 & 6 & $\overline{2} 11$ & $<5$ & 1.531 & & 1.532 & 3 & 302 \\
\hline & & 2.245 & 1 & 211 & $<5$ & 1.519 & & 1.521 & 2 & 215 \\
\hline 6 & 2.212 & 2.216 & 2 & 131 & $<5$ & 1511 & & 1.514 & 2 & 135 \\
\hline$<5$ & 2.204 & 2.215 & 4 & 131 & $<3$ & 1.511 & & 1.512 & 3 & 135 \\
\hline 10 & 2.185 & 2.181 & 5 & $\overline{2} 02$ & $<5$ & 1.505 & & 1.505 & 5 & $\overline{3} 12$ \\
\hline 10 & 2.185 & 2.177 & 2 & 202 & $<5$ & 1.503 & & 1.503 & 4 & 312 \\
\hline & & 2.158 & 10 & $\overline{1} 14$ & 5 & & & 1.470 & 9 & $\overline{3} 21$ \\
\hline 11 & 2.156 & 2.154 & 6 & 114 & 3 & $1.46 /$ & & 1.469 & 10 & 321 \\
\hline 6 & 2099 & 2.099 & 5 & $\overline{2} 12$ & $<5$ & 1.463 & & 1.464 & 2 & $\overline{1} 44$ \\
\hline 0 & 2.093 & 2.095 & 6 & 212 & $<5$ & 1.458 & & 1.463 & 3 & 144 \\
\hline 12 & 2.072 & 2.073 & 15 & 132 & 5 & 1.443 & & 1.447 & 4 & $\overline{2} 34$ \\
\hline 12 & 2.012 & 2.071 & 10 & 132 & 10 & 1.438 & & 1.439 & 5 & 225 \\
\hline 6 & 2.044 & 2.047 & 5 & 033 & $<5$ & 1.429 & & 1.429 & 9 & $\overline{3} 13$ \\
\hline 0 & 2.044 & 2.046 & 1 & 220 & $<5$ & 1.365 & & 1.365 & 0 & $\overline{2} 16$ \\
\hline 21 & 2.006 & 2.006 & 21 & $\overline{2} 21$ & $<5$ & 1.355 & & 1.357 & 6 & 0227 \\
\hline 21 & 2.000 & 2.005 & 24 & 221 & $<5$ & 1347 & & 1.349 & 7 & 153 \\
\hline$<5$ & 1.963 & 1.963 & 5 & 015 & J & 1 & & 1.348 & 7 & 153 \\
\hline$<5$ & 1.929 & 1.929 & 9 & 040 & & & & 1.344 & 1 & $\overline{1} 45$ \\
\hline 11 & 1.908 & 1.906 & 22 & $\overline{2} 13$ & $<5$ & 1.341 & & 1.342 & 2 & 145 \\
\hline 18 & 1.901 & 1.901 & 22 & 213 & $<5$ & 1.306 & & 1.307 & 6 & 127 \\
\hline & & 1.896 & 1 & 222 & -3 & 1.500 & & 1.305 & 7 & 127 \\
\hline 16 & 1.892 & 1.895 & 4 & 041 & & & & 1.236 & 6 & 340 \\
\hline & & 1.886 & 3 & 133 & $<5$ & 1.233 & \{ & 1.234 & 2 & 161 \\
\hline & & 1.820 & 4 & $\overline{1} 15$ & & & & 1.233 & 3 & 161 \\
\hline 0 & 1.815 & 1.816 & 3 & 115 & $<5$ & 1.227 & & 1.228 & 4 & 055 \\
\hline
\end{tabular}


study of isostructural datolite and herderite (Frost et al., 2013, 2014; Goryainov et al., 2015) the most intense Raman bands at 897 and $970 \mathrm{~cm}^{-1}$ are assigned to stretching vibrations of $\mathrm{Be}-\mathrm{O}$ and $\mathrm{Si}-\mathrm{O}$ in tetrahedral coordination. The bands in the region $200-750 \mathrm{~cm}^{-1}$ are assigned to banding modes of $\mathrm{Si}-\mathrm{O}$ and $\mathrm{Be}-\mathrm{O}$, stretching vibrations of $R E E-\mathrm{O}$ and $\mathrm{Fe}-\mathrm{O}$ and to lattice vibrations. The weak band at $3525 \mathrm{~cm}^{-1}$ is attributed to stretching vibrations of $\mathrm{OH}$ units in the gadolinite structure. The local maximum at $3370 \mathrm{~cm}^{-1}$ is caused by luminescence as proven by excitation using a $532 \mathrm{~nm}$ laser.

\section{$X$-ray crystallography and structure determination}

Powder X-ray diffraction data for gadolinite-(Nd), carefully extracted from the polished section by a diamond microgrinder and powdered under isopropyl alcohol in an agate mortar, were obtained using an
Empyrean (PANalytical) powder diffractometer with the solid-state PIXcel ${ }^{3 \mathrm{D}}$ detector operating in BraggBrentano geometry. Data were collected over the range of $5-80^{\circ} 2 \theta$ with a step size of $0.013^{\circ}$ and counting time of $2 \mathrm{~s}$ per step. Positions and intensities of diffraction maxima were obtained from a profile fitting performed with High-Score3 software (PANalytical). Unit-cell parameters were refined using least-squares based on the positions of 40 reflections utilizing Celref software (Laugier and Bochu, 2004). The experimental powder pattern was indexed in accordance with the calculated values of intensities obtained from the single-crystal structure refinement. Powder X-ray diffraction data are given in Table 5. Unit-cell parameters refined from the powder data are $a=4.826(1), b=7.717(2), c=10.147(2) \AA$, $\beta=90.16^{\circ}$ and $V=377.9(2) \AA^{3}$.

A platy crystal fragment $(0.07 \mathrm{~mm} \times 0.06 \mathrm{~mm} \times$ $0.01 \mathrm{~mm}$ ) was examined on an Oxford Diffraction Gemini single-crystal diffractometer with Atlas S2 $\mathrm{CCD}$ detector, using monochromatized $\mathrm{MoK} \alpha$

TABLE 6. Summary of data collection conditions and refinement parameters for gadolinite-(Nd).

\begin{tabular}{|c|c|}
\hline \multirow{2}{*}{\multicolumn{2}{|c|}{$\begin{array}{l}\text { Structural formula } \\
\text { Unit-cell parameters }\end{array}$}} \\
\hline & \\
\hline$a, b, c[\AA]$ & $4.8216(3), 7.6985(4), 10.1362(6)$ \\
\hline B & $90.234(4)$ \\
\hline$V\left[\AA^{3}\right]$ & $376.24(6)$ \\
\hline$Z$ & 2 \\
\hline Space group & $P 2_{1} / c$ \\
\hline$D_{\text {calc }}\left(\mathrm{g} \mathrm{cm}^{-3}\right)$ & 5.044 \\
\hline Temperature & $301 \mathrm{~K}$ \\
\hline Wavelength & $\mathrm{MoK} \alpha, 0.7107 \AA$ \\
\hline Crystal dimensions (mm) & $0.069 \times 0.059 \times 0.019$ \\
\hline Collection mode & $\omega$ scans to fill an Ewald sphere \\
\hline Frame width $\left(^{\circ}\right)$, counting time & $1.0,170 \mathrm{~s}$ \\
\hline Limiting $\theta$ angles & $3.32-28.16^{\circ}$ \\
\hline Limiting Miller indices & $-6<h<6,-10<k<9,-13<l<12$ \\
\hline No. of reflections & 2955 \\
\hline No. of unique reflections & 875 \\
\hline No. of observed reflections (criterion) & $607[I>3 \sigma(I)]$ \\
\hline Absorption correction $\left(\mathrm{mm}^{-1}\right)$, method & 15.483, Gaussian \\
\hline$T_{\min } / T_{\max }$ & $0.6512 / 0.8619$ \\
\hline$R_{\text {int }}$ & 0.106 \\
\hline$F_{000}$ & 518 \\
\hline Refinement by Jana2006 on $F^{2}$ & \\
\hline Parameters, constraints, restraints & $57,18,0$ \\
\hline$R_{1}, w R_{2}$ (obs) & $0.0371,0.0780$ \\
\hline$R_{1}, \mathrm{w} R_{2}$ (all) & $0.0581,0.0877$ \\
\hline Goof (obs, all) & $1.14,1.05$ \\
\hline Weighting scheme, weights & $\sigma, 1 /\left(\sigma^{2}(F)+0.0004 F^{2}\right)$ \\
\hline$\Delta \rho_{\min }, \Delta \rho_{\max }\left(e \AA^{-3}\right)$ & $-1.21,1.56$ \\
\hline
\end{tabular}


radiation $(\lambda=0.71073 \AA)$ from a conventional sealed X-ray tube and collimated with fibre optics and Mo-Enhance collimator. The unit cell was refined from 1323 reflections using least-squares with the Crysalis software (2014, Agilent Technologies, Oxford, UK); $\omega$ rotational scans (frame width $1^{\circ}$, counting time $170 \mathrm{~s}$ per frame) were adopted to collect a set of three-dimensional intensity data. From a total of 2955 reflections, 875 were independent and 607 classified as observed, with $\left[I_{\text {obs }}>3 \sigma(I)\right]$. Corrections for background, Lorentz effects and polarization were applied; Gaussian correction for absorption (shape + empirical scaling) was done in JANA2006 (Petrríček et al., 2014) giving a data set with $R_{\text {int }}$ of $\sim 10 \%$. Reduction of the data was performed using the Crysalis package. The crystal structure of gadolinite(Nd) was refined from single-crystal data using the structure model for gadolinite-(Y) published in Demartin et al. (1993) by full-matrix least-squares using JANA2006 (Petrríček et al., 2014) based on $F^{2}$. All non-oxygen atoms were refined with anisotropic displacement parameters. Refinement for 57 parameters and 18 constraints converged to $R=0.0371, w R=0.0780$ for 607 observed reflections $(\mathrm{Goof}=1.14)$. Details of data collection, crystallographic data and refinement details are given in Table 6. Atom coordinates and displacement parameters are listed in Table 7; selected interatomic distances are provided in Table 8 .

The structure refinement of gadolinite-(Nd) provides no significant departure from the published structure results of the isostructural gadolinite-(Y) (Miyawaki et al., 1984; Demartin et al., 1993; Cámara et al., 2008). Minerals of the gadolinite group possess a layer structure composed of two distinct sheets, which are alternating in the $\mathbf{c}$ direction (Bačík et al., 2014). One sheet is represented by $T \mathrm{O}_{4}$ and $Q_{4}$ tetrahedra and it alternates with a second sheet of $A \mathrm{O}_{8}$ polyhedra and $M \mathrm{O}_{6}$ octahedra. In the structure of gadolinite-(Nd), the $T$-site is occupied dominantly by $\mathrm{Si}^{4+}$, the $Q$-site by Be, the $A$-site by $\mathrm{Nd}^{3+}$ (and other $R E E)$ and the $M$-site by $\mathrm{Fe}^{2+}$. During the refinement we treated $A$-sites as only occupied by Nd. We did not model substitutions of a large number of REE that have very similar scattering curves for X-rays as we are convinced that such a fit would not make much sense. The refined site occupancies for $\mathrm{Nd}$ and $\mathrm{Be}$ turned out they be slightly lower than unity (due to the effects of mixing with lighter elements at particular sites). The $\mathrm{Mg}$ substitution for $\mathrm{Fe}$, as documented from the wavelength-dispersive spectroscopy analyses, was not successfully confirmed by the structure refinement. The structural formula for gadolinite-

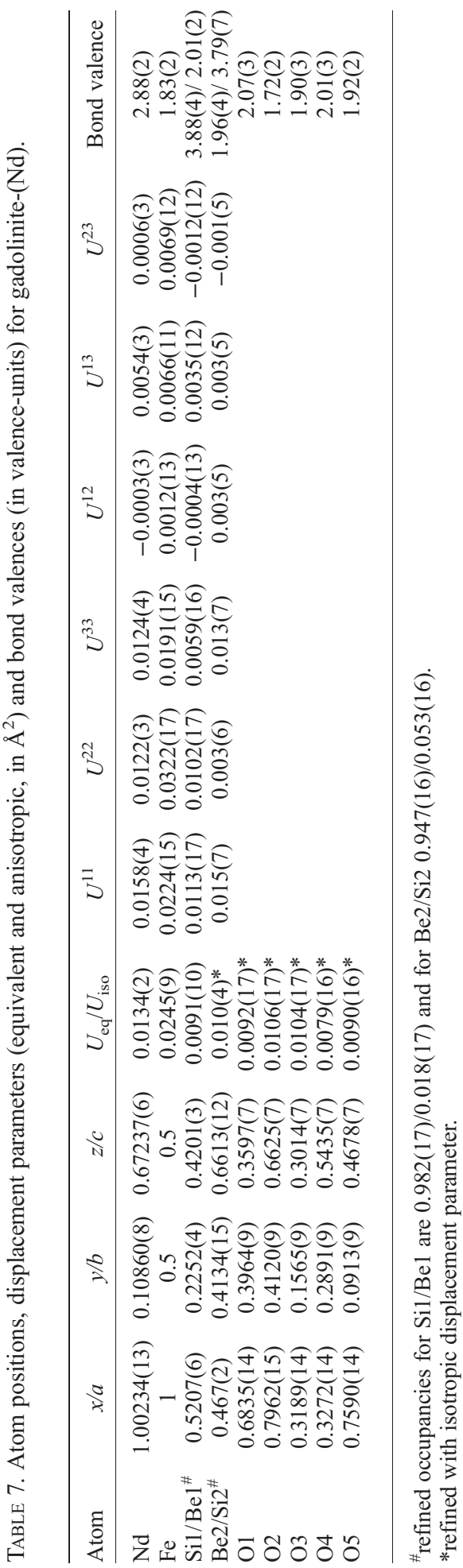


TABLE 8. Selected interatomic distances (in $\AA$ ) in the structure of gadolinite-(Nd).

\begin{tabular}{|c|c|c|c|}
\hline $\mathrm{Nd}-\mathrm{O} 1^{\mathrm{i}}$ & $2.448(7)$ & $\mathrm{Fe}-\mathrm{O} 1$ & $2.229(7)$ \\
\hline $\mathrm{Nd}-\mathrm{O} 2$ & $2.540(7)$ & $\mathrm{Fe}-\mathrm{O} 1^{\mathrm{vii}}$ & $2.229(7)$ \\
\hline $\mathrm{Nd}-\mathrm{O} 2^{\mathrm{ii}}$ & $2.455(7)$ & $\mathrm{Fe}-\mathrm{O} 2$ & $2.037(7)$ \\
\hline $\mathrm{Nd}-\mathrm{O} 3^{\mathrm{iii}}$ & $2.576(7)$ & $\mathrm{Fe}-\mathrm{O} 2^{\mathrm{vii}}$ & $2.037(7)$ \\
\hline $\mathrm{Nd}-\mathrm{O}{ }^{\text {iv }}$ & $2.701(7)$ & $\mathrm{Fe}-\mathrm{O} 4^{\mathrm{v}}$ & $2.305(7)$ \\
\hline $\mathrm{Nd}-\mathrm{O}^{\mathrm{v}}$ & $2.471(7)$ & $\mathrm{Fe}-\mathrm{O} 4^{\text {viii }}$ & $2.305(7)$ \\
\hline $\mathrm{Nd}-\mathrm{O} 5$ & $2.382(7)$ & $<\mathrm{Fe}-\mathrm{O}>$ & 2.190 \\
\hline $\mathrm{Nd}-\mathrm{O} 5^{\mathrm{vi}}$ & $2.392(7)$ & & \\
\hline$<\mathrm{Nd}-\mathrm{O}>$ & 2.496 & & \\
\hline $\mathrm{Si1} / \mathrm{Be} 1-\mathrm{O} 1$ & $1.653(7)$ & $\mathrm{Be} 2 / \mathrm{Si} 2-\mathrm{O} 1^{\text {viii }}$ & $1.646(13)$ \\
\hline $\mathrm{Si} 1 / \mathrm{Be} 1-\mathrm{O} 3$ & $1.633(8)$ & $\mathrm{Be} 2 / \mathrm{Si} 2-\mathrm{O} 2$ & $1.589(14)$ \\
\hline $\mathrm{Si} 1 / \mathrm{Be} 1-\mathrm{O} 4$ & $1.639(7)$ & $\mathrm{Be} 2 / \mathrm{Si} 2-\mathrm{O}{ }^{\mathrm{ix}}$ & $1.680(14)$ \\
\hline $\mathrm{Si} 1 / \mathrm{Be} 1-\mathrm{O} 5$ & $1.616(7)$ & $\mathrm{Be} 2 / \mathrm{Si} 2-\mathrm{O} 4$ & $1.669(13)$ \\
\hline$<\mathrm{Si} 1 / \mathrm{Be} 1-\mathrm{O}>$ & 1.635 & $<\mathrm{Be} 2 / \mathrm{Si} 2-\mathrm{O}>$ & 1.646 \\
\hline $\mathrm{Si} 1 / \mathrm{Be} 1-\mathrm{Be} 2 / \mathrm{Si} 2$ & $2.855(12)$ & & \\
\hline $\mathrm{Si} 1 / \mathrm{Be} 1-\mathrm{Be} 2 / \mathrm{Si} 2^{\text {viii }}$ & $2.903(11)$ & & \\
\hline $\mathrm{Si} 1 / \mathrm{Be} 1-\mathrm{Be} 2 / \mathrm{Si}^{\mathrm{ix}}$ & $2.843(12)$ & & \\
\hline
\end{tabular}

Symmetry codes: (i) $x,-y+1 / 2, z+1 / 2$; (ii) $-x+2, y-1 / 2,-z+3 / 2$; (iii) $-x+$ $1,-y,-z+1$; (iv) $x+1,-y+1 / 2, z+1 / 2$; (v) $x+1, y, z$; (vi) $-x+2,-y,-z+1$; (vii) $-x+2,-y+1,-z+1$; (viii) $-x+1,-y+1,-z+1$; (ix) $x,-y+1 / 2, z-1 / 2$; (x) $-x+1, y+1 / 2,-z+1 / 2$.

(Nd) is therefore $\mathrm{Nd}_{1.942} \mathrm{FeBe}_{1.931} \mathrm{Si}_{2.069} \mathrm{O}_{10}, Z=2$. This formula is not electro-neutral due to the fact that the refined occupancies are only a proxy to the real situation, the refinement of all (excluding REE) substituting components is beyond the quality of current dataset. However, the refinement of the data suggested that a small amount of $\mathrm{Si}$ can enter the $Q$-sites and vice-versa.

\section{Concluding remarks}

Rare-earth element ores from the Bastnäs-type deposits are in general characterized by $L R E E$ enriched and HREE depleted patterns (e.g. Holtstam et al., 2014). Taking into consideration the low activity of $\mathrm{P}$ and elevated activity of $\mathrm{CO}_{2}$, the primary $R E E$ minerals are represented as silicates and carbonates. Among the REE phases of the Bastnäs-type mineralization at the Malmkärra mine, the gadolinite-group minerals together with fluorbritholite represent the phases which accommodate the highest amount of middlerare-earth elements (MREE) and HREE into their structure. On the other hand, epidote-supergroup minerals, including västmanlandite, are strongly depleted in MREE and HREE (Fig. 2).
Notably, the new mineral may represent a locally important sink for the critical metal neodymium in deposits of the Bastnäs-type. Geijer (1936) reported törnebohmite as occurring locally in "not insignificant amounts" at Malmkärra, while Holtstam and Andersson (2007) make no mention of having observed this mineral. Considering their, in part similar, optical properties, it seems possible that Geijer's törnebohmite could represent (a misidentified) gadolinite. Additionally, new observations also suggest that it may be more abundant than hitherto known in other Bastnäs-type mineralizations, specifically in the Johanna and Nya Bastnäs mines.

\section{Acknowledgements}

The authors are grateful to Peter Bačík, Daniel Atencio, an anonymous reviewer and the Structures Editor Peter Leverett for constructive criticism that significantly improved the manuscript, as well as to Editor John Bowles for careful handling of the manuscript. Voting members of the IMA-CNMNC are acknowledged for the constructive remarks to the proposal. This study was supported by the research projects GAČR P210/14/1347S and MUNI/A/1005/ 2013 for RŠ and RČ and MN. Single-crystal X-ray diffraction experiments were done using instruments 
of the ASTRA lab established within the Operation program Prague Competitiveness - project CZ.2.16/ $3.1 .00 / 24510$. EJ acknowledges support from the Swedish Research Council (VR) and the Geological Survey of Sweden (SGU) to projects on rare and critical metals in central Sweden at Uppsala University. MVG acknowledges CEITEC 2020 (LQ1601) project with financial contribution made by the Ministry of Education, Youth and Sports of the Czech Republic within special support paid from the National Program for Sustainability II Funds.

\section{References}

Andersson, U.B. (2004) The Bastnäs-type REEmineralisations in north-western Bergslagen, Sweden. Sveriges Geologiska Undersökning Rapporter and Meddelanden, 119, 34.

Bačík, P., Fridrichová, J., Uher, P., Pršek, J. and Ondrejka, M. (2014) The crystal chemistry of gadolinite-datolite group silicates. The Canadian Mineralogist, 52, 625-642.

Bačík, P., Miyawaki, R., Atencio, D., Cámara, F. and Fridrichová, J. (2017) Nomenclature of the Gadolinite Supergroup. European Journal of Mineralogy, 29, $1-16$.

Bergstøl, S. and Juve, G. (1988) Scandian ixiolite, pyrochlore and bazzite in granite pegmatite in Tørdal, Telemark, Norway. A contribution to the mineralogy and geochemistry of scandium and tin. Mineralogy and Petrology, 38(4), 229-243.

Bjørlykke, H. (1935) The mineral paragenesis and classification of the granite pegmatites of Iveland, Setesdal, South Norway. Norsk Geologisk Tidsskrift 14, 211-311.

Bonazzi, P., Bindi, L. and Parodi, G. (2003) Gatelite-(Ce), a new REE-bearing mineral from Trimouns, French Pyrenees: Crystal structure and polysomatic relationships with epidote and törnebohmite-(Ce). American Mineralogist, 88, 223-228.

Brotzen, O. (1959). Mineral-Association in Granitic Pegmatites: A Statistical Study. Geologiska Föreningen i Stockholm Förhandlingar, 81, 231-296.

Cámara, F., Oberti, R., Ottolini, L., Della Ventura, G. and Bellatreccia, F. (2008) The crystal chemistry of Li in gadolinite. American Mineralogist, 93, 996-1004.

Černý, P. (1991) Rare-element granitic pegmatites, Part 1. anatomy and internal evolution of pegmatite deposits. Geoscience Canada, 18, 49-67.

Demartin, F., Pilati, T., Diella, V., Gentile, P. and Gramaccioli, C.M. (1993) A crystal-chemical investigation of alpine gadolinite. The Canadian Mineralogist, 30, 127-136.

Ekeberg, A.G. (1802) Upplysning om ytterjordens egenskaper, i synnerhet i jämförelse med Berylljorden: om de fossilier, hvari förstnämnde jord innehålles, samt om en ny upptäckt kropp af metallisk natur. Kongliga Vetenskaps Academiens Nya Handlingar, 23, 68-83.

Frost, R.L., Xi, Y., Scholz, R., Lima, R.M.F., Horta, L.F.C. and Lopez, A. (2013) Thermal analysis and vibrational spectroscopic characterization of the boro silicate mineral datolite- $\mathrm{CaBSiO}_{4}(\mathrm{OH})$. Spectrochimica Acta Part A: Molecular and Biomolecular Spectroscopy, 115, 376-381.

Frost, R.L., Scholz, R., López, A., Xi, Y., de Siqueira Queiroz, C., Belotti, F.M. and Cândido Filho, M. (2014) Raman, infrared and near-infrared spectroscopic characterization of the herderite-hydroxylherderite mineral series. Spectrochimica Acta Part A: Molecular and Biomolecular Spectroscopy, 118, 430-437.

Gadolin, J. (1794) Undersökning af en svart tung stenart ifrån Ytterby stenbrott $\mathrm{i}$ Roslagen. Kongliga Vetenskaps Academiens Nya Handlingar, 15, $137-155$.

Geijer, P. (1936) Norbergs berggrund och malmfyndigheter. Sveriges Geologiska Undersökning, Ca 24, 162 pp.

Geijer, P. (1961) The geological significance of the cerium mineral occurrences of the Bastnäs type in central Sweden. Arkiv för mineralogi och geologi, 3, 99-105.

Geijer, P. and Magnusson, N. H. (1944) De mellansvenska järnmalmernas geologi. Sveriges Geologiska Undersökning, Ca 35, 654 pp.

Goodenough, K.M., Schilling, J., Jonsson, E., Kalvig, P., Charles, N., Tuduri, J., Deady, E.A., Sadeghi, M., Schiellerup, H., Müller, A., Bertrand, G., Arvanitidis, N., Eliopolous, D.G., Shaw, R.A., Thrane, K. and Keulen, N. (2016) Europe's rare earth element resource potential: an overview of metallogenetic provinces and their geodynamic setting. Ore Geology Reviews, 72, 838-856.

Goryainov, S.V., Krylov, A.S., Vtyurin, A.N. and Pan, Y. (2015) Raman study of datolite $\mathrm{CaBSiO}_{4}(\mathrm{OH})$ at simultaneously high pressure and high temperature. Journal of Raman Spectroscopy, 46, 177-181.

Haynes, C.V. (1965) Genesis of the White Cloud and related pegmatites, South Platte Area, Jefferson County, Colorado. Geological Society of America Bulletin, 76, 441-462.

Holtstam, D. and Andersson U. (2007) The REE minerals of the Bastnäs-type deposits, south-central Sweden. The Canadian Mineralogist, 45, 1073-1114.

Holtstam, D., Kolitsch, U. and Andersson, U.B. (2005) Västmanlandite-(Ce)-a new lanthanide-and F-bearing sorosilicate mineral from Västmanland, Sweden. European Journal of Mineralogy, 17, 129-141.

Holtstam, D., Andersson, U.B., Broman C. and Mansfeld, J. (2014) Origin of REE mineralization in the Bastnäs-type Fe-REE-(Cu-Mo-Bi-Au) deposits, Bergslagen, Sweden. Mineralium Deposita, 49, 933-966. 
Jonsson, E. and Högdahl, K. (2013) New evidence for the timing of formation of Bastnäs-type REE mineralisation in Bergslagen, Sweden. Mineral Deposit Research for a High-Tech World - Proceedings of the 12th Biennial SGA Meeting, Uppsala, Sweden, 1724-1727.

Jonsson, E., Högdahl, K., Sahlström, F., Nysten, P. and Sadeghi, M. (2014) The Palaeoproterozoic skarnhosted REE mineralisations of Bastnäs-type: overview and mineralogical-geological character. ERES2014: 1st European Rare Earth Resources Conference, Milos - Book of abstracts, 382-390.

Kjellman, J., Černý, P. and Smeds, S.A. (1999) Diversified NYF pegmatite populations of the Swedish Proterozoic: Outline of a comparative study. The Canadian Mineralogist, 37, 832-833.

Laugier, J. and Bochu, B. (2004) LMPG Suite of Programs for the Interpretation of X-ray Experiments. ENSP/Laboratoire des Matériaux et du Génie Physique, BP 46. 38042 Saint Martin d'Hères, France. URL: http://www.ccp14.ac.uk/tutorial/lmgp/ (Accessed: 05 January 2017).

Lenz, C., Nasdala, L., Talla, D., Hauzenberger, C., Seitz, R. and Kolitsch, U. (2015) Laser-induced $\mathrm{REE}^{3+}$ photoluminescence of selected accessory minerals An "advantageous artefact" in Raman spectroscopy. Chemical Geology, 415, 1-16.

Lyalina, L.M., Selivanova, E.A., Savchenko, Y.E., Zozulya, D.R. and Kadyrova, G.I. (2014) Minerals of the gadolinite-(Y)-hingganite-(Y) series in the alkali granite pegmatites of the Kola Peninsula. Geology of Ore Deposits, 56, 675-684.

McDonough, W.F. and Sun, S.S. (1995) The composition of the Earth. Chemical Geology, 120, 223-253.

Merlet, C. (1994) An accurate computer correction program for quantitative electron probe microanalysis. Microchimica Acta, 114/115, 363-376.

Miyawaki, R., Nakai, I. and Nagashima, K. (1984) A refinement of the crystal structure of gadolinite. American Mineralogist, 69, 948-953.

Miyawaki, R., Matsubara, S., Yokoyama, K. and Okamoto, A. (2007) Hingganite-(Ce) and hingganite(Y) from Tahara, Hirukawa-mura, Gifu Prefecture, Japan: The description on a new mineral species of the Ce-analogue of hingganite-(Y) with a refinement of the crystal structure of hingganite-(Y). Journal of Mineralogical and Petrological Sciences, 102, 1-7.

Nasdala, L., Beyssac, O., Schopf, J.W. and Bleisteiner B. (2012) Application of Raman-based images in the Earth sciences. Pp. 145-187 in: Raman Imaging Techniques and Applications (A. Zoubrir, editor). Springer Series Opti, 168. Springer, Berlin -Heidelberg.
Nilssen, B. (1973) Gadolinite from Hundholmen, Tysfjord, North Norway. Norsk Geologisk-Tidsskrift, 53, 343-348.

Pekov, I.V., Pasero, M., Yaskovskaya, A.N., Chukanov, N. V., Pushcharovsky, D.Y., Merlino, S., Zubkova, N.V., Kononkova, N.N., Menshikov, Y.P. and Zadov, A.E. (2007) Fluorcalciobritholite, $(\mathrm{Ca}, \mathrm{REE})_{5}\left[(\mathrm{Si}, \mathrm{P}) \mathrm{O}_{4}\right]_{3} \mathrm{~F}$, a new mineral: description and crystal chemistry. European Journal of Mineralogy, 19, 95-103.

Petříček, V., Dušek, M. and Palatinus, L. (2014) Crystallographic computing system JANA2006: general features. Zeitschrift für Kristallographie, 229, 345-352.

Pezzotta, F., Diella, V. and Guastoni, A. (1999) Chemical and paragenetic data on gadolinite-group minerals from Baveno and Cuasso al Monte, southern Alps, Italy. American Mineralogist, 84, 782-789.

Pieczka, A., Hawthorne, F.C., Cooper, M.A., Szełęg, E., Szuszkiewicz, A., Turniak, K., Nejbert, K. and Ilnicki, S. (2015) Pilawite-(Y), $\mathrm{Ca}_{2}(\mathrm{Y}, \mathrm{Yb})_{2}\left[\mathrm{Al}_{4}\left(\mathrm{SiO}_{4}\right)_{4} \mathrm{O}_{2}\right.$ $\left.(\mathrm{OH})_{2}\right]$, a new mineral from the Piława Górna granitic pegmatite, southwestern Poland: mineralogical data, crystal structure and association. Mineralogical Magazine, 79, 1143-1157.

Pršek, J., Ondrejka, M., Bačík, P., Budzyń, B. and Uher, P. (2010) Metamorphic-hydrothermal REE minerals in the Bacúch magnetite deposit, Western Carpathians, Slovakia: (Sr, S)-rich monazite-(Ce) and Nd-dominant hingganite. The Canadian Mineralogist, 48, 81-94.

Sahlström, F., Jonsson, E., Högdahl, K., Harris, C., Troll, V.R. and Jolis, E.M. (2015) O and C isotope study of Bastnäs-type rare earth element mineralisation, Bergslagen, Sweden. PacRim 2015 conference Book of abstracts, 439-443.

Segalstad, T.V. and Larsen, A.O. (1978) Gadolinite-(Ce) from Skien, southern Oslo region, Norway. American Mineralogist, 63, 188-195.

Škoda, R., Cempírek, J., Filip, J., Novák, M., Veselovský, F. and Čtvrtlík, R. (2012) Allanite-(Nd), $\mathrm{CaNdAl}_{2} \mathrm{Fe}^{2+}$ $\left(\mathrm{SiO}_{4}\right)\left(\mathrm{Si}_{2} \mathrm{O}_{7}\right) \mathrm{O}(\mathrm{OH})$, a new mineral from Åskagen, Sweden. American Mineralogist, 97, 983-988.

Škoda, R., Plášil, J., Jonsson, E., Čopjaková, R., Langhof, J. and Vašinová Galiová, M. (2015) Redefinition of thalénite-(Y) and discreditation of fluorthalénite-(Y): A re-investigation of type material from the Österby pegmatite, Dalarna, Sweden, and from additional localities. Mineralogical Magazine, 79, 965-984.

Smeds, S.A. (1990) Regional trends in mineral assemblages of Swedish Proterozoic granitic pegmatites and their geological significance. Geologiska Föreningens i Stockholm Förhandlingar, 112, 227-242.

Vorma, A., Ojanperä, P., Hoffren, V., Siivola, J. and Löfgren, A. (1966) On the rare earth minerals from the Pyörönmaa pegmatite in Kangasala. Comptes Rendu de la Société Geologique de Finlande, 38, 241-274. 